\title{
DETECTION OF ORAL STREPTOCOCCI IN DENTAL BIOFILM FROM CARIES-ACTIVE AND CARIES-FREE CHILDREN
}

\author{
Andréa Cristina Barbosa da Silva ${ }^{1,2 *}$; Jader dos Santos Cruz ${ }^{2,3}$; Fábio Correia Sampaio ${ }^{1}$; \\ Demetrius Antônio Machado de Araújo ${ }^{2}$ \\ ${ }^{1}$ Departamento de Odontologia Clínica e Social, Universidade Federal da Paraíba, João Pessoa, PB, Brasil; ${ }^{2}$ Departamento de \\ Biologia Molecular, Universidade Federal da Paraíba, João Pessoa, PB, Brasil; ${ }^{3}$ Departamento de Bioquímica e Imunologia, \\ Universidade Federal de Minas Gerais, Belo Horizonte, MG, Brasil
}

Submitted: October 23, 2007; Returned to authors for corrections: February 25, 2008; Approved: October 22, 2008.

\section{SHORT COMMUNICATION}

\begin{abstract}
This work correlated the presence of oral streptococci in dental biofilm with clinical indexes of caries and oral hygiene in caries-active and caries-free children. S. mutans and/or S. sobrinus in the dental biofilm does not indicate a direct risk for developing dental caries.
\end{abstract}

Key words: dental caries; dental biofilm; oral streptococci; PCR; glucosyltranferases

It is well established that microorganisms have an important role in caries etiology (13). The oral streptococci, especially Streptococcus mutans and Streptococcus sobrinus have often been associated with dental caries in humans (18). Other microorganisms, such as Streptococcus mitis and Streptococcus salivarius have also been linked with the disease or absence of it. Their interplay within the dental biofilm is an important feature for the establishment and maintenance of the oral microflora and the development of a cariogenic dental plaque (16).

The detection and identification of oral streptococci in the dental biofilm is considered to be an important step for the understanding of dental caries. Several methods have been proposed to identify and differentiate oral streptococci: biochemical tests (24), immunologic and genetic methods with DNA probes (4), microbiologic methods (21), polymerase chain reaction (PCR) (8) and variations of this technique, such as real-time PCR (26) and nested PCR (22). The PCR method is faster, more sensitive and specific than the current microbiologic methods (9).

However, for clinical studies, the best predictor of dental caries is the past caries experience. This information is limited since the caries risk can be already established (2).
The aim of the present study was to correlate the presence of oral streptococci in the dental biofilm of children with different caries patterns, using specific primers to identify $S$. mutans, $S$. sobrinus and $S$. salivarius using the PCR technique.

Ten children were invited to participate in this study according to the following inclusion criteria: age ranging from 6-8 yr; studying in the same school an under same dietary pattern; presenting erupted permanent molars and different pattern of dental caries activity (DMFT/dmft $>0$ or DMFT/ $\mathrm{dmft}=0$ ). Children taking any medication during the study were excluded. The protocol was approved by the Ethical Board of the Health Science Center at the Federal University of Paraíba (protocol 231/04), and informed consent was obtained from the children's parents.

The clinical indexes obtained were: gingival bleeding index (GBI); simplified oral hygiene index (OHI-S) (6), and dental caries (DMFT and dmft) (25). The following salivary tests were also carried out: salivary flow rate, buffer capacity and oral streptococci counting (OSC).

The dental biofilm samples were obtained from the buccal surface of the first (deciduous or permanent) molar on the left side of the lower jaw, using sterile dentine spoons. The material

*Corresponding Author. Mailing address: Andréa C. B. Silva Departamento de Biologia Molecular/UFPB. Cidade Universitária. Castelo Branco. CEP: 58051-900. João Pessoa, PB, Brasil. Tel.: +55 833216 7436; fax: +55 833216 7787. E-mail: andreacbsilva@gmail.com 
was dispersed in sterile tubes containing brain heart infusion (BHI; Difco). After biofilm collection, the children were instructed to chew paraffin wax for $5 \mathrm{~min}$, and then to spit into a sterile tube. The stimulated saliva and biofilm samples were kept on ice, transported immediately to the laboratory and examined within $2 \mathrm{~h}$ of collection.

The buffer capacity was obtained adding $1 \mathrm{ml}$ of saliva to 3 $\mathrm{ml}$ of $\mathrm{HCl}(0.005 \%)$, and the final $\mathrm{pH}$ was measured.

The oral streptococci count was obtained after serially diluting the saliva samples with sterilized saline, inoculating on MS agar plates, and incubating at $37^{\circ} \mathrm{C}$ for 2 days in a $5 \% \mathrm{CO}_{2}-$ enriched atmosphere. The microorganisms from saliva and dental biofilm samples were routinely cultured in brain heart infusion broth (BHI) (Difco, USA), mitis salivarius agar (MSA) (Difco, USA) and mitis salivarius agar supplemented with $440 \mathrm{mmol} \mathrm{l}^{-1}$ sucrose, $39 \mathrm{mmol} \mathrm{l}^{-1}$ potassium tellurite and 0.2 units $\mathrm{ml}^{-1}$ of bacitracin (MSB).

Saliva samples were vortexed for $30 \mathrm{~s}$ and serially diluted $(1: 10,1: 100$ and 1:100) in isotonic saline solution. The samples were then inoculated on MSB agar plates, in duplicate and incubated at $37^{\circ} \mathrm{C}$ for $2 \mathrm{~d}$ in a $5 \% \mathrm{CO}_{2}$-enriched atmosphere. Before the examination, the plates were left at room temperature for $24 \mathrm{~h}$. To avoid bias, all plates were processed and examined by the same investigator. Colonies of oral streptococci were identified morphologically and counted. The results are expressed as (CFU) $\mathrm{ml}^{-1}$. The dental biofilm samples dispersed in BHI were vortexed for $30 \mathrm{~s}$, plated in duplicate on agar plates of MS and MSB and incubated at $37^{\circ} \mathrm{C}$ for $2 \mathrm{~d}$ in a $5 \% \mathrm{CO}_{2}$-enriched atmosphere. Aliquots of oral streptococci from the dental biofilm samples were stored in tubes containing Skin Milk medium (Difco, USA).

The microorganisms $(100 \mu \mathrm{l})$ stocked in Skin Milk were grown in $5 \mu \mathrm{l}$ of $\mathrm{BHI}$ at $37^{\circ} \mathrm{C}$ for $24 \mathrm{~h}$ in a $5 \% \mathrm{CO}_{2}$-enriched atmosphere. DNA extraction from the microorganisms of the dental biofilm samples were carried out according to Buikema et al. (3), modified. The samples were kept at $-20^{\circ} \mathrm{C}$.

PCR was conducted using specific primers for the glucosyltransferase (GTF) enzyme to detect $S$. mutans, $S$. sobrinus and S. salivarius (Hoshino et al., 2004 (8), modified). The PCR products were analyzed by $2.0 \%$ agarose gel electrophoresis, after staining with ethidium bromide. The gels were photodocumented using ImageMaster (Amersham Pharmacia Biotech, USA) for subsequent analysis.

The product size in each species was in accordance with the expected size. No results were found for S. sobrinus. $S$. salivarius was identified in $80 \%$ of dental biofilm samples cultivated in MSA and 55.5\% in MSB. S. mutans was identified in $60 \%$ of the dental biofilm samples cultivated in MSA and $78 \%$ in MSB (Table 1).

Table 1. Oral streptococcal species detected by PCR from dental biofilm samples cultivated in medium MSA and MSB.

\begin{tabular}{|c|c|c|c|c|c|c|c|c|c|c|}
\hline \multirow{2}{*}{$\begin{array}{l}\text { Caries risk } \\
\text { Patient no.* }\end{array}$} & \multicolumn{5}{|c|}{ High caries activity (DMFT/dmft>0) } & \multicolumn{5}{|c|}{ Low caries activity (DMFT/dmft=0) } \\
\hline & 1 & 3 & 5 & 6 & 7 & 2 & 4 & 8 & 9 & 10 \\
\hline Age & 7 & 7 & 8 & 7 & 7 & 7 & 6 & 7 & 7 & 7 \\
\hline dmf-t** & 4 & 3 & 9 & 6 & 2 & 0 & 0 & 0 & 0 & 0 \\
\hline $\mathrm{DMF}-\mathrm{T} \dagger$ & 1 & 4 & 4 & 4 & 1 & 0 & 0 & 0 & 0 & 0 \\
\hline OHI-S & 1.5 & 1.83 & 2.0 & 1.8 & 1.16 & 2.16 & 0.83 & 1.16 & 1.33 & 1.16 \\
\hline GBI§ & 6.25 & 2.17 & 8.33 & 6.8 & 5.00 & 7.29 & 1.31 & 6.25 & 4.76 & 1.08 \\
\hline \multicolumn{11}{|l|}{ MSA } \\
\hline S. mutans & $+\S \S$ & + & + & + & + & $-\S \S$ & + & - & - & - \\
\hline S. sobrinus & 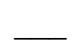 & 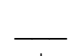 & 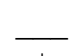 & - & 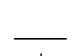 & 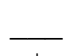 & - & - & 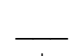 & - \\
\hline S. salivarius & - & + & + & $\overline{-}$ & + & + & + & + & + & + \\
\hline \multicolumn{11}{|l|}{ MSB } \\
\hline S. mutans & $+\S \S$ & + & + & - & + & - & + & - & + & + \\
\hline S. sobrinus & $-\S \S$ & - & - & - & - & - & - & - & - & - \\
\hline S. salivarius & - & + & - & + & - & - & + & - & + & + \\
\hline
\end{tabular}

*Dental biofilm samples obtained from ten 6-8-year-old children.

$* *$ dmf-t, decayed and filled deciduous tooth index.

$\dagger$ DMF-T, decayed and filled permanent tooth index.

†OHI-S, simplified oral hygiene index.

$\S \mathrm{GBI}$, percentage of gingival bleeding index.

$\S \S+$, detected in PCR; -, not detected in PCR.

\#There was no growth of microorganisms in the dental biofilm sample cultivated in MSB from patient 2. 
There was no clear relationship between caries experience and caries activity as well as oral streptococci counting (OSC). Some studies found a relationship between high OSC (above $10^{6} \mathrm{UFC} / \mathrm{ml}$ ) and high caries indexes $(5,15)$. On the other hand, Loesche and Straffon (12) demonstrated that caries can occur in the absence of S. mutans and Matee et al. (14) observed that the level of oral streptococci in the saliva of children cannot predict future caries.

Correlations between salivary tests (including OSC) and patients with high caries activity and low caries activity were not observed. These findings are in accordance with Sundin et al. (23) who also found a weak or non-existent relationship between these variables. However, Ravald and Birkhed (20) demonstrated that individuals with low salivary flow rate have a higher predisposition to cariogenic activity.

In the present work, MSB medium selected the microorganisms of the mutans group (S. mutans and S. sobrinus) and $S$. salivarius of the salivarius group. These findings are in accordance with Yoo et al. (27) who concluded that MSB medium is not specific for selecting streptococci of the mutans group, suggesting that a new selective medium is required for reliable isolation of mutans streptococci.

In this work, $S$. mutans and $S$. salivarius were identified in the dental biofilm of patients with HCA and LCA(Table 1). The association between $S$. mutans with $S$. sobrinus and carious lesions has been observed previously. The differentiation between S. mutans and S. sobrinus is important due to their different behavior in the initial colonization phase and different virulence mechanism (11). Considering the cariogenicity of S. salivarius, few studies related this bacterium with dental caries (1).

$S$. sobrinus is frequently present at a lower level than $S$. mutans (17) due to its inability to carry $N$-acetylglucosamine. This is an energy-requiring process which depletes the intracellular levels of phosphoenolpyruvate (7) and reduces the energy inside the microorganism that can be used for other purposes. MSB medium can also inhibit the growth of $S$. sobrinus. Pereira et al. (19) demonstrated that $S$. mutans has ability to inhibit plaque formation by $S$. sobrinus and recolonize surfaces. Individuals with increased numbers of mutans streptococci and lactobacilli were associated with increasing prevalence of caries (10).

Few studies have evaluated the prevalence of $S$. salivarius in dental biofilm. In general, this microorganism is identified on the tongue. In this study, this microorganism was frequently identified in cultivated samples of dental biofilm in MSA and MSB, as well in patients with HCA and LCA. Similar findings were observed by Hoshino et al. (8), who identified this microorganism in 9 of the 10 salivary samples analyzed in cariesfree patients, and patients with high caries indexes (DMFT and $\mathrm{dmft})$. S. salivarius showed a high prevalence in dental biofilm samples in this study, and it can cooperate with $S$. mutans to form a cariogenic dental plaque. This must be investigated further in future studies.

In spite of the low number of patients in our study, it could be expected that if a direct and strong correlation between OSC and dental caries takes place, this relationship could be differentiated between these carious risk groups. The unclear relation of specific microorganisms and clinical caries parameters support the hypothesis that other factors are necessary to be operating for caries development (e.g. lack of oral hygiene and/ or a sugar rich diet). Nevertheless, the multifactorial etiology for dental caries does not invalidate the use of PCR for microorganism detection since this technique can be a reliable tool for bacteria identification in the complex biofilm environment. Finally, it can be concluded that the presence of S. mutans and/ or S. sobrinus in the dental biofilm does not indicate a direct risk for the development of dental caries.

\section{ACKNOWLEDGMENTS}

We are grateful for the technical assistance of Amely Branquinho Martins and Teresa Cristina S. L. Grisi. We are also thankful to Itácio Padilha and Marcela Lins. This work was supported by CAPES and CNPq.

\section{RESUMO}

\section{Detecção de estreptococos orais em biofilme dental de crianças cárie-ativas e livres de cárie}

Este trabalho correlacionou a presença de estreptococos orais no biofilme dental com índices clínicos de cárie dentária e higiene oral em crianças com alta e baixa atividade de cárie. $S$. mutans e/ou S. sobrinus no biofilme dental não significa o imediato desenvolvimento de lesões cariosas.

Palavras-chave: cárie dentária; biofilme dental, estreptococos orais; PCR; glicosiltransferases.

\section{REFERENCES}

1. Brailsford, S.R.; Shah, B.; Simons, D.; Gilbert, S.; Clark, D.; Ines, I.; Adams, S.E.; Allison, C.; Beighton, D. (2001). The predominant aciduric microflora of root-caries lesions. J. Dent. Res., 80: 1828-1833.

2. Bratthall, D. (1996). Dental caries: intervened-interruptedinterpreted. Concluding remarks and cariography. Eur. J. Oral Sci., 104: 486-491.

3. Buikema, W.J.; Klingensmith, J.A.; Gibbons, S.L.; Ausubel, F.M. (1987). Conservation of structure and location of Rhizobium meliloti and Klebsiella pneumoniae nifB genes. J. Bacteriol., 169: 11201126.

4. Conrads, G. (2002). DNA probes and primers in dental practice. Clin. Infect. Dis., 35(Suppl 1): 72S-77S.

5. Fujiwara, T.; Sasada, E.; Mima, N.; Ooshima, T. (1991). Caries prevalence and salivary mutans streptococci in 0-2-years-old children of Japan. Community Dent. Oral Epidemiol., 19: 151-154. 
6. Greene, J.C.; Vermillion, J.R. (1964). The simplified oral hygiene index. J. Am. Dent. Assoc., 68: 7-13.

7. Homer, K.A.; Patel, R.; Beighton, D. (1993). Effects of Nacetylglucosamine on carbohydrate fermentation by Streptococcus mutans NCTC 10449 and Streptococcus sobrinus SL-1. Infect. Immun., 61: 295-302.

8. Hoshino, T.; Kawagushi, M.; Shimizu, N.; Hoshino, N.; Ooshima, T.; Fujiwara, T. (2004). PCR detection and identification of oral streptococci in saliva samples using gtf genes. Diagn. Microb. Infect. Dis., 48: 195-199.

9. Igarashi, T.; Yamamoto, A.; Goto, N. (1996). Direct detection of Streptococcus mutans in human dental plaque by polymerase chain reaction. Oral Microbiol. Immunol., 5: 294-298.

10. Köhler, B.; Bjarnason, S. (1992). Mutans streptococci, lactobacilli and caries prevalence in 15 to 16 -year olds in Goteborg. Part II. Swed. Dent. J., 16: 253-259.

11. Loesche WJ. (1986). Role of Streptococcus mutans in human dental decay. Microbiol. Rev., 50: 2118-2135.

12. Loesche, W.J.; Straffon, L.H. (1979). Longitudinal investigations of the role of Streptococcus mutans in human fissure decay. Infect. Immun., 26: 498-507.

13. Marsh PD. (2000). Role of the oral microflora in health. Microb Ecol. Health Dis., 12: 130-137.

14. Matee, M.I.N.; Mikx, F.H.M.; Soet, J.S.; Maselle, S.Y.; Graaff, J.; van Palenstein Helderman, W.H. (1993). Mutans streptococci in caries-active and caries-free infants in Tanzanis. Oral Microbiol. Immunol., 8: 322-324.

15. Mattos-Graner, R.O.; Smith, D.J.; King, W.F.; Mayer, M.P. (2000). Water-insoluble glucan synthesis by mutans streptococcal strains correlates with caries incidence in 12 - to 30 -month-old children. $J$. Dent. Res., 76: 371-1377.

16. Nyvad, B.; Kilian, M. (1990). Comparison of the initial streptococcal microflora on dental enamel in caries-active and in caries-inactive individuals. Caries Res., 24: 267-272.
17. Okada, M.; Soda, Y.; Hayashi, F.; Doi, T.; Suzuki, J.; Miura, K.; Kozai, K. (2002). PCR detection of Streptococcus mutans and S. sobrinus in dental plaque samples from Japanese pre-school children. J. Med. Microbiol., 51: 443-447.

18. Okada, M.; Soda, Y.; Hayashi, F.; Doi, T.; Suzuki, J.; Miura, K.; Kozai, K. (2005). Longitudinal study of dental incidence associated with Streptococcus mutans and Streptococcus sobrinus in pre-school children. J. Med. Microbiol., 54: 661-665.

19. Pereira, C.V.; Pereira, L.J.; Gonçalves, R.B.; Höfling, J.F. (2006). In vitro bacterial plaque suppression and recolonization by $S$. mutans and S. sobrinus. Braz. J. Microbiol., 37:20-25.

20. Ravald, N.; Birkhed, D. (1991). Factors associated with active and inactive root caries in patients with periodontal disease. Caries Res., 25: $377-384$.

21. Sanchez-Perez, L.; Acosta-Gio, A.E. (2001). Caries risk assessment from dental plaque and salivary Streptococcus mutans counts on two culture media. Arch. Oral Biol., 46: 49-55.

22. Sato, T.; Matsuyama, J.; Kumagai, T.; Mayanagi, G.; Yamaura, M.; Washio, J.; Takahashi, N. (2003). Nested PCR for detection of mutans streptococci in dental plaque. Lett. Appl. Microbiol., 37: 66-69.

23. Sundin, B.; Granath, L.; Birkhed, D. (1992). Variation of posterior approximal caries incidence with consumption in sweets with regard to other caries-related factors in 15-18 years-old. Community Dent. Oral Epidemiol., 20: 76-80.

24. Whiley, R.A.; Beighton, D. (1998). Current classification of the oral streptococci. Oral Microbiol. Immunol., 13: 195-216.

25. WHO. (1987). Oral health surveys: basic methods. $3^{\text {rd }}$ ed. Geneva: World Health Organization, 53.

26. Yano, A.; Kaneko, N.; Ida, H.; Yamaguchi, T.; Hanada, N. (2002) Real-time PCR for quantification of Streptococcus mutans. FEMS Microbial. Lett., 217: 23-30.

27. Yoo, S.Y.; Kim, P.S.; Hwang, H.K.; Lim, S.H.; Kim, K.W.; Choe, S.J.; Min, B.M.; Kook, J.K. (2005). Identification of non-mutans streptococci organisms in dental plaques recovering on mitis-salivarius bacitracin agar medium. J. Microbiol., 43: 204-208. 